\title{
Foreign body penetrations of hand and wrist: a retrospective study
}

\author{
El ve el bileğinin yabancı cisim penetrasyon yaralanmaları: \\ Retrospektif çalışma
}

\author{
Emre HOCAOĞLU, ${ }^{1}$ Samet Vasfi KUVAT, ${ }^{1}$ Burhan ÖZALP, ${ }^{2}$ Anvar AKHMEDOV, ${ }^{1}$ \\ Yunus DOĞAN, ${ }^{1}$ Erol KOZANOĞLU, ${ }^{1}$ Fethi Sarper METE, ${ }^{1}$ Metin ERER ${ }^{1}$
}

\section{BACKGROUND}

Despite significant practical knowledge and experience on foreign body penetration injuries to the hand and/or wrist, deficient management and complications can still be encountered, and ignorance of its causative and eventual social aspects unfortunately is a substantial fact. This study aims to cover the clinical and social properties and the management of these kinds of injuries.

\section{METHODS}

A retrospective analysis of 86 patients requiring evaluation and treatment in a Hand Surgery Division of a university hospital was performed.

\section{RESULTS}

The median age was 32 (min: 4, max: 63). Industrial workers constituted the largest occupational group $(n=22$, $25.6 \%)$. Twenty-three $(26.7 \%)$ of the cases were elective admissions. Thirteen (15.1\%) patients had various comorbidities, and five $(5.8 \%)$ had psychiatric diagnoses at the time of the injury. The index finger was the most frequent site of injury ( $n=29,33.7 \%)$. General anesthesia was not necessary for the management of $94.2 \%$ of the cases. In 26 $(30 \%)$ of the patients, neural, tendinous or osseous damage was observed. Twenty-four $(30 \%)$ patients were included in a postoperative hand physiotherapy program.

\section{CONCLUSION}

The practically well-known general features of the issue and those aspects that may still be overlooked currently are reevaluated herein, in light of our observational data.

Key Words: Foreign body; hand; penetration injury; wrist.

\section{AMAC}

Konuyla ilgili ileri seviyedeki pratik bilgi birikimimize rağmen, el ve elbileğinin yabancı cisim penetrasyon yaralanmaları, halen eksik tedaviler ve komplikasyonlarla gündeme gelebilmektedir. Konunun sosyal, etyolojik ve hukuki boyutu günlük yoğun pratik içinde atlanabilmektedir. Bu çalışmada, konunun sosyal, klinik ve terapötik özellikleri ele alındı.

\section{GEREÇ VE YÖNTEM}

Bir el cerrahisi kliniğince tedavisi yapılmış 86 hastanın retrospektif analizi yapıldı.

\section{BULGULAR}

Ortalama yaşı 32 olan popülasyonun \%25,6's1 endüstriyel işçilerden (en kalabalık mesleki grup) oluşmaktaydı. Başvuruların \%26,7'si elektif idi. Yaralanma döneminde ek hastal1ğ olanlar popülasyonun \%15,1'ini, psikiyatrik tanısı olanlar \%5,8'ini oluşturuyordu. İşaret parmağı en sık yaralanan bölge $(\% 33,7)$ idi. Ameliyatların \%94,2'si lokal anestezi altında yapıld1. \%30 hastada nöral, tendinöz ve/veya kemiksel hasar mevcuttu. Hastaların \%30'u ameliyat sonrası el fizyoterapi programına dahil edildiler.

\section{SONUÇ}

El ve elbileğinin yabancı cisim penetrasyon yaralanmaları genel yönleri ve pratikte gözden kaçabilen özellikleri ile ele alındı.

Anahtar Sözcükler: Yabanc1 cisim; el; penetrasyon yaralanmas1; el bileği.
${ }^{1}$ Department of Plastic Reconstructive and Aesthetic Surgery,

Istanbul University, Istanbul Faculty of Medicine, Istanbul;

${ }^{2}$ Department of Plastic Reconstructive and Aesthetic Surgery,

Dicle University Faculty of Medicine, Diyarbakır, Turkey.
Iİstanbul Üniversitesi, İstanbul Tıp Fakültesi, Plastik Rekonstrüktif ve Estetik Cerrahi Anabilim Dalı, İstanbul ${ }^{2}$ Dicle Üniversitesi Tip Fakültesi, Plastik Rekonstrüktif ve Estetik Cerrahi Anabilim Dalı, Diyarbakır. 
Foreign body (FB) penetrations of the hand and wrist constitute an important type of injury that is frequently encountered in primary health care units, emergency rooms and hand surgery departments. These usually appear as emergency cases, but the number of patients met under elective conditions cannot be underestimated. A FB, stuck into an extremity, may lead to consequences such as tissue damage, inflammation, infection, delayed wound healing, toxic or allergic reactions, and late injury as a result of migration. ${ }^{\left[{ }^{1]}\right.}$ When the anatomic properties are taken into consideration, even a tiny object, penetrated through a small skin laceration, may damage significant structures of the hand and wrist where many structures are tightly arranged.

There has been an increasing number of case reports in the literature presenting striking injuries of various body parts associated with FB penetrations. However, the number of observational studies about hand and wrist penetrations is limited when compared to the high prevalence of subjects. In spite of the substantial experience of clinicians on this issue, there are a significant number of articles denoting defective management strategies, such as inadequate tetanus prophylaxis, and uncertainty in basic principles such as selecting the right solution for wound irrigation. ${ }^{[2,3]}$ Moreover, wounds with neglected FBs form one of the high-risk emergency medicine categories responsible for malpractice events. ${ }^{[4]}$ Indeed, failure to diagnose or treat retained FBs has been reported to be the fifth leading claim against emergency physicians. [5] This study thus aims to reveal the basic features of the affected patients, the properties of the penetrated objects, the events causing this specific type of injury, the management of these injuries, and the outcomes of the patients. It is based on an analysis of a group of patients who had FB injuries in a more specific anatomic location, i.e. the hand and wrist.

\section{MATERIALS AND METHODS}

This study was approved by the Institutional Ethics Committee and is based on a retrospective analysis of patients who had hand and/or wrist injuries caused by FB penetration. Eighty-six patients, who had been treated by the staff of the Department of Plastic Reconstructive and Aesthetic Surgery (PRAS) between $01 / 12 / 2004$ and $01 / 12 / 2011$, were included in the study. Patients had been referred to the Hand Surgery Division (HSD) of the Department of PRAS either from the Emergency Department (ED) of the same hospital or from EDs of other hospitals and primary health care units.

Age, sex, occupation and social status, presence of any accompanying diseases or psychiatric disorders, specific anatomic localization of the FB penetration, injured structure(s), type of anesthesia used, nature of each FB, type of event that resulted in the injury, and presence of any legal component of the event were noted for each case. Almost all of these data were obtained from the medical record cards. All the patients were also telephoned to obtain informed consent for the study, gather any data that were unavailable on the cards and query the patients regarding any complaints related to the site of injury.

Occupational features and social status of patients were incorporated in eight separate titles as: unemployed, housewives, retirees, students, industrial workers, service sector workers, civil servants, and others. For each case, the specific anatomic site of entrance of the FB was allocated into one of eleven groups as: first web space, thumb, index finger, middle finger, ring finger, small finger, hypothenar area, thenar area, hand dorsum, wrist, and carpal tunnel. In terms of injured structures, patients were categorized into one of eight groups as: skin laceration only, digital pulp laceration, nail bed injury, extensor tendon injury, flexor tendon injury, nerve injury, phalangeal fracture, and multiple structural injuries. The types of anesthesia used for the surgery were analyzed. Patients were also categorized as fully recovered or having at least one complaint related to the specific injured site. Data obtained in terms of the structural properties of penetrated FBs could be distributed in 11 groups as: metal splinters, wooden splinters, glass pieces, dyestuff, sewing needles, fish hooks, bullets, nails, pencils, crochet hooks, and other metal objects. Events that resulted in FB penetrations to the hand and wrist were classified in 6 groups as: occupational accidents, accidents occurring during the conduct of daily chores, traffic accidents, deliberate behaviors aimed at secondary gains, pathological behaviors as part of psychiatric disorders, and injuries occurring due to criminal acts. Finally, whether the patient presented as an emergency case or the referral was elective was also noted for each case.

The presented results are objectified by adding remarkable case examples of different types of etiologic bases.

\section{RESULTS}

The median age of the 86 patients was 32 (min: 4, max: 63). The demographic data including the distribution of patients to the age groups are demonstrated in Table 1 . Sixteen $(18.6 \%)$ patients were being treated or followed up because of one or more additional health problems, including psychiatric disorders, at the time of their injury. The results of analysis of the data that pertains to the anatomical sites of entrance of the FBs, injured structures, affected side of the body, and frequency of postoperative complaints about the injured site are also listed in Table 1.

As summarized in Table 2, the underlying events and the etiologic bases of these injuries were com- 
Table 1. Demographic and clinical features of the patients

\begin{tabular}{|c|c|c|}
\hline Variables & $\mathrm{n}$ & $\%$ \\
\hline \multicolumn{3}{|l|}{ Age } \\
\hline$<1$ & 0 & 0.0 \\
\hline $1-4$ & 2 & 2.3 \\
\hline $5-14$ & 10 & 11.6 \\
\hline $15-24$ & 19 & 22.1 \\
\hline $25-34$ & 20 & 23.3 \\
\hline $35-44$ & 21 & 24.4 \\
\hline $45-54$ & 7 & 8.1 \\
\hline $55-64$ & 7 & 8.1 \\
\hline $65-74$ & 0 & 0.0 \\
\hline \multicolumn{3}{|l|}{ Gender } \\
\hline Male & 60 & 69.8 \\
\hline Female & 26 & 30.2 \\
\hline \multicolumn{3}{|l|}{ Extra disease } \\
\hline None & 70 & 81.4 \\
\hline Extra medical problems & 13 & 15.1 \\
\hline Psychiatric disorder & 5 & 5.8 \\
\hline \multicolumn{3}{|l|}{ Occupation } \\
\hline Industrial worker & 22 & 25.6 \\
\hline Student & 17 & 19.8 \\
\hline Service sector worker & 13 & 15.1 \\
\hline Civil servant & 8 & 9.3 \\
\hline Unemployed & 7 & 8.1 \\
\hline Housewife & 6 & 7.0 \\
\hline Retired & 6 & 7.0 \\
\hline Others & 5 & 5.8 \\
\hline \multicolumn{3}{|l|}{ Foreign body entrance site } \\
\hline Index finger & 29 & 33.7 \\
\hline Middle finger & 10 & 11.6 \\
\hline Wrist & 10 & 11.6 \\
\hline Thenar area & 9 & 10.5 \\
\hline Thumb & 7 & 8.1 \\
\hline Hypothenar area & 5 & 5.8 \\
\hline Carpal tunnel & 4 & 4.7 \\
\hline First web & 4 & 4.7 \\
\hline Small finger & 4 & 4.7 \\
\hline Hand dorsum & 2 & 2.3 \\
\hline Ring finger & 2 & 2.3 \\
\hline \multicolumn{3}{|l|}{ Injury } \\
\hline Skin laceration & 44 & 51.2 \\
\hline Digital pulp laceration & 11 & 12.8 \\
\hline Nerve & 8 & 9.3 \\
\hline Multiple tissue injury & 8 & 9.3 \\
\hline Nail bed & 5 & 5.8 \\
\hline Extensor tendon & 4 & 4.7 \\
\hline Flexor tendon & 4 & 4.7 \\
\hline Phalanx fracture & 2 & 2.3 \\
\hline \multicolumn{3}{|l|}{ Side } \\
\hline Left & 45 & 52.3 \\
\hline Right & 41 & 47.7 \\
\hline \multicolumn{3}{|l|}{ Postoperative complaint } \\
\hline None & 71 & 82.6 \\
\hline
\end{tabular}

posed of $44(51.2 \%)$ accidents that occurred during the conduct of daily chores and hobbies (Figs. 1a, b), 30 (34.9\%) occupational accidents (Figs. 1c, d), 4 (4.7\%) traffic accidents, $4(4.7 \%)$ pathological behaviors as consequences of psychiatric disorders, 3 (3.5\%) criminal activities (Fig. 1e), and 1 (1.2\%) deliberate behavior for a secondary gain (Fig. 1f). After the operations, the follow-up of $40(46.5 \%)$ patients was done in the HSD outpatient clinic, and $24(60 \%)$ of these 40 patients were included in a hand physiotherapy program. The analysis of admission patterns, the diagnostic and therapeutic workups of the patients and the features of the FBs are also demonstrated in Table 2.

Among 23 elective admissions, 7 patients stated that they had not sought any professional healthcare for their injuries; thus, they had not received any tetanus prophylaxis within the acute phase of the injury although they had had received no vaccination during the previous 10 years. The remaining 63 patients who applied as emergency cases were given tetanus prophylaxis on the day of injury, according to the Advisory Committee on Immunization Practices recommendations. ${ }^{[6,7]}$

\section{DISCUSSION}

Compatible with our findings, FB penetrations of the hand and/or wrist usually present as emergency cases, but elective applications of patients with embedded objects are not uncommon. Embedded FBs can also be removed from patients who are unaware or uncertain of FB entry. ${ }^{[8]}$ Accidents that happen during the conduct of daily chores, hobbies and occupational activities are the most frequent causes of FB penetrations. In fact, $86.1 \%$ of the cases analyzed in our study were due to such accidents, almost all of which resulted in isolated local injuries to the trauma site. On the other hand, they may also occur as minor or major components of multiple trauma cases, as in traffic accidents. Conscious behaviors performed for self-mutilation or secondary gain are other forms of etiologic bases for FB penetrations.

When an embedded FB is suspected due to the medical history and examination, plain radiography, ultrasonography or computed tomography may be used as imaging techniques. It is usually possible to find the embedded FBs through using two-view plain radiographs. We utilized two-view X-rays in $74.4 \%$ of our patients. For some cases, sticking radiopaque materials to the skin or wound surface and/or inserting metal grids such as syringe needles to the soft tissue just before taking the radiographs was beneficial. In some centers, fluoroscopy is also being utilized as a routine component of the surgery. ${ }^{[9]}$ Previously, it has been stated that the two-view X-rays have been shown to be equivalent to the three-view X-rays in detecting glass FBs. ${ }^{[10]}$ In another study, when only plain films 

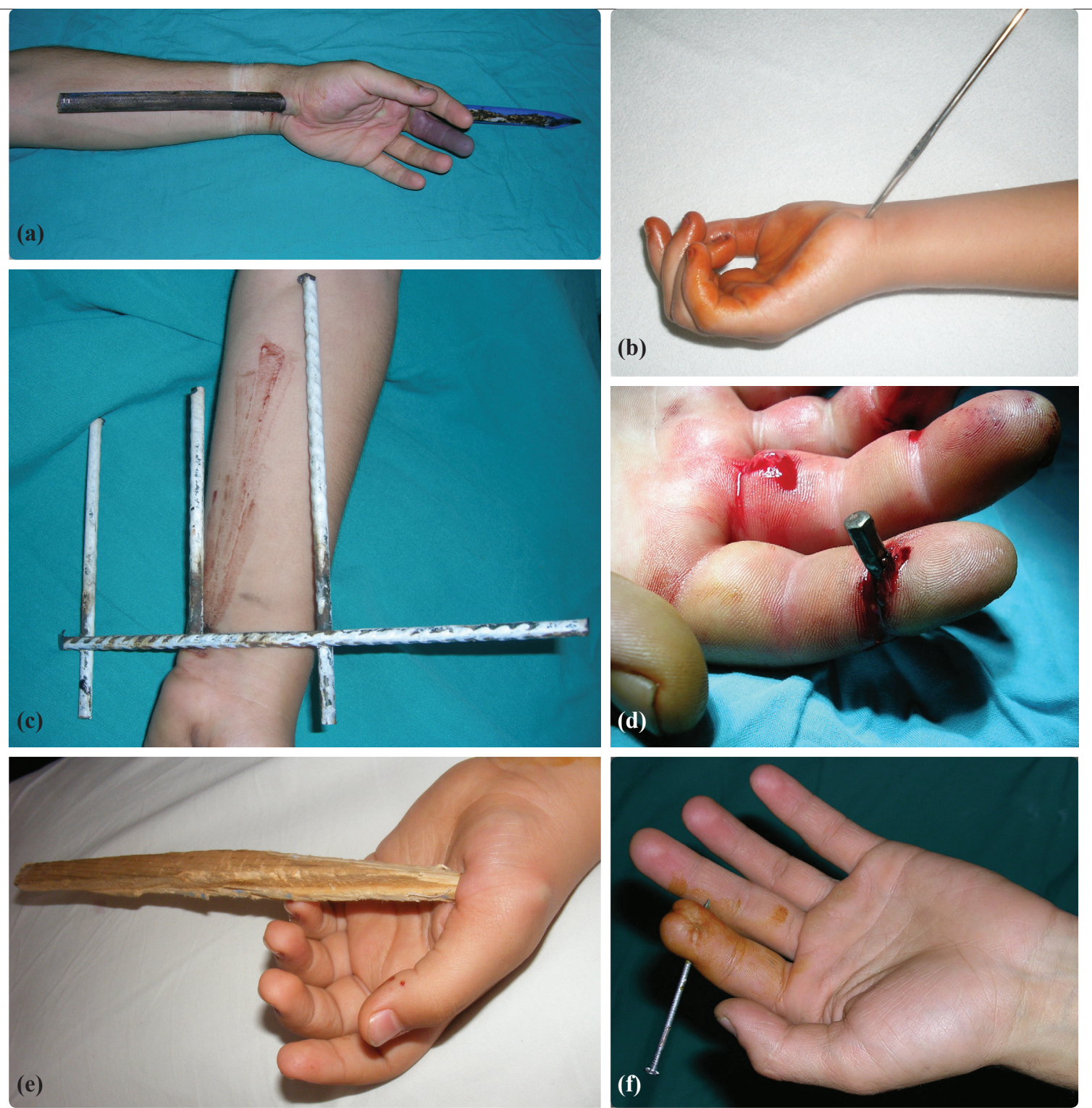

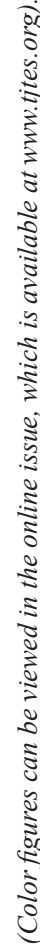

Fig. 1. (a) A 21-year-old university student was found hanging by his hand, through which a metallic extension of the garden wall had penetrated. This had occurred while attempting to jump over the wall. He presented with a large piece of the metal railing, which had penetrated through almost the entire length of his left hand. Under general anesthesia, the palmar skin surrounding the FB was opened using Bruner zigzag incisions, and the palmar fascia was passed. The FB was observed to extend between the branches of the median nerve and the digital neurovascular bundles, dissecting but not damaging them. The FB and the involved tissues were lubricated with sterile liquid petroleum jelly. The huge FB was extracted carefully from between the surrounding dissected nerves and vessels. (b) After an accident that had occurred during the conduct of household chores, a 14-year-old girl presented with a crochet-hook stuck in the ulnar side of her wrist. The depth and localization of the hooked tip was estimated through two-view plain radiographs. Even though there were no symptoms or clinical findings regarding a neurovascular or tendon injury, exploration of the site was carried out due to the possibility of damage to the ulnar artery or ulnar nerve. Under loupe magnification, it was seen that the FB had penetrated through the fascicles of the ulnar nerve without causing any ruptures. (c) A 27 -year-old male industrial worker was brought to us with a metal mesh penetrating his wrist as a result of an occupational accident. He stated that during a sudden period of drowsiness, he had tried to hold the metal mesh to stop a fall, but the free edge of the object had penetrated his wrist. While radiographs were being taken, the FB was extracted spontaneously despite our routine effort to keep the object still in the wound. Exploration of the site revealed a partially damaged ulnar nerve. (d) A 37-year-old industrial worker with a metal object stuck in his finger was referred to us after an occupational accident. Under local anesthesia, the wound was extended with incisions made proximally and distally on the mid-lateral line. Next, the palmar neurovascular structures, the flexor and extensor tendons, were explored, and the FB was extracted. Finally, the radial collateral ligament and articular surfaces of the middle and distal phalanges were examined. After massive irrigation of the site, the partially damaged flexor tendon and the radial collateral ligament were repaired, and the skin was closed primarily. (e) An 11-year-old student was admitted to our clinic because one of his school friends had intentionally stuck a sharp-pointed piece of wood into his right thenar area. Just after the physical examination, a median and radial nerve block was performed at the wrist level. The two-view radiography showed the embedded tip of the object with no extra splinters of wood around it. Under general anesthesia, after extending the wound with incisions, the FB was extracted through the thenar muscles. Exploration revealed no neurovascular or tendinous damage. (f) A 42-year-old prison inmate presented with a nail stuck in his finger stump, which had been operated previously because of another accident. It was reported as an odd accident or was claimed to be an accident involving nail gun usage during voluntary repair work at the prison. The FB had penetrated the entire width of the finger by passing through the middle phalanx. The entrance and exit points of the nail were just on the mid-lateral lines. The nail was removed by traction under local anesthesia without extra incision, and the wounds were left for secondary healing. 
were utilized, wood and glass FBs were missed in $93 \%$ and $25 \%$ of the cases, respectively, so ultrasound was suggested to be the more sensitive and preferred technique for imaging of wooden FBs. ${ }^{[11]}$ We used no imaging in $25.6 \%$ of the cases in which significant parts of the FBs were visible externally. Whatever the chosen imaging technique, it is very important to keep still the injured extremity and the FB during the clinical evaluations and radiological investigations in order to prevent injury to surrounding structures.

In $55.7 \%$ of our cases, the FBs were metallic, while they were glass and wood in $23.3 \%$ and $11.6 \%$ of the cases, respectively. The chemical and physical properties of the embedded FB influence the clinical evaluation and intervention processes. The risk of the damage that emerges as a consequence of leaving the FB in place and the risk of surgical intervention for exploration and removal of the object should be compared, and the action should be taken accordingly. Case reports of embedded organic FBs such as splinters of plants, wood and fish fin fragments demonstrate the typical clinical picture of inflammatory reaction that develops in days or weeks. ${ }^{[12]}$ In this sense, metal objects are less risky than the organic ones ${ }^{[13]}$ For this reason, if the exploration and extraction attempts have the risk of injury to the neighboring structures, it is better to leave an embedded inert metal object in its place unless it causes any symptoms or infection. However, it should not be forgotten that soft-tissue FBs that are missed on the initial evaluation may migrate to cause significant morbidity, or even mortality, months or years after the traumatic event. ${ }^{[1,8]}$

In case of penetrations with remarkable-sized objects, estimation of the location and the course of the FB in the tissue are usually easier, but removal of the object without damaging the surrounding tissues is obviously the most challenging part of the management. Even if there are no symptoms or findings of a structural injury, removing the FB blindly just by extraction is indisputably an error. This action will most likely be detrimental to the regional structures. With respect to our findings, $36 \%$ of the cases had an injury of either a neurovascular or a tendinous structure, or combinations thereof. In general, it is crucial to extend the wound with incisions that will allow exploration of the FB, or the penetrated part of it, and the structures in close proximity.

The type of anesthesia is determined by considering the location of the FB, the depth of penetration, the most likely injured structure(s), the age and psychological status of the patient, and the predicted duration of the operation. Our study demonstrates the great importance of local and regional anesthesia in cases of FB penetrations of the hand and wrist, as $94.2 \%$ of our cases were operated under local infiltrations, digital blocks, and blocks at the wrist, elbow and axilla.
Table 2. Characteristics of the injuries, events and details about the management

\begin{tabular}{|c|c|c|}
\hline Variables & $\mathrm{n}$ & $\%$ \\
\hline \multicolumn{3}{|l|}{ Status } \\
\hline Emergency & 63 & 73.3 \\
\hline Elective & 23 & 26.7 \\
\hline \multicolumn{3}{|l|}{ Etiology } \\
\hline Daily chores accident & 44 & 51.2 \\
\hline Occupational accident & 30 & 34.9 \\
\hline Psychiatric disorder & 4 & 4.7 \\
\hline Traffic accident & 4 & 4.7 \\
\hline Criminal & 3 & 3.5 \\
\hline Secondary gains & 1 & 1 \\
\hline \multicolumn{3}{|l|}{ Substance } \\
\hline Glass & 20 & 23.3 \\
\hline Sewing needle & 13 & 15.1 \\
\hline Wooden splinter & 12 & 14.0 \\
\hline Metal splinter & 10 & 11.6 \\
\hline Crochet hook & 5 & 5.8 \\
\hline Dyestuff & 3 & 3.5 \\
\hline Nail & 3 & 3.5 \\
\hline Pencil & 3 & 3.5 \\
\hline Bullet & 2 & 2.3 \\
\hline Fishhook & 2 & 2.3 \\
\hline Other metal objects & 13 & 15.1 \\
\hline \multicolumn{3}{|l|}{ Radiology } \\
\hline Two-view radiograph & 64 & 74.4 \\
\hline None & 22 & 25.6 \\
\hline \multicolumn{3}{|l|}{ Anesthesia } \\
\hline Local infiltration and/or digital block & 75 & 87.2 \\
\hline Regional block & 6 & 7.0 \\
\hline General anesthesia & 5 & 5.8 \\
\hline \multicolumn{3}{|l|}{ Postoperative follow-up } \\
\hline By us & 40 & 46.5 \\
\hline By family physician & 30 & 34.9 \\
\hline None & 16 & 18.6 \\
\hline \multicolumn{3}{|l|}{ Rehabilitation } \\
\hline None & 62 & 72.1 \\
\hline Hand physiotherapy & 24 & 27.9 \\
\hline
\end{tabular}

The best means of preventing infection is debridement and massive irrigation of the site just after removal of the object. In general, decontamination is far more important than antibiotics. ${ }^{[14]}$ We carry out the massive irrigation process -to which we add scrubbing for some wounds- first by diluted povidone-iodine (PVP-I) solution (1\% PVP-I), followed by sterile normal saline solution. Some authors suggest avoiding usage of anti-septic solutions such as PVP-I, chlorhexidine, and hydrogen peroxide for irrigation due to the fact that they have toxic effects on the tissues and slow down the healing process. ${ }^{[13]}$ On the contrary, in a review study, articles with superior level of evidence were analyzed, and it was seen that $71 \%$ of the litera- 
ture supports the use of PVP-I, and refutes the hypothesis that there is a negative impact on tissue regeneration. ${ }^{[3]}$ Another effective and more practical alternative for wound irrigation might be tap water, especially in pediatric cases. ${ }^{[15]}$ The damaged tissues can be repaired and/or primary closure can be carried out provided the irrigation procedure is adequately accomplished. Our decision to use antimicrobials and to continue antibiotic prophylaxis in the postoperative period is individualized for each patient, and this modality parallels the recommendations in the literature. ${ }^{[16]}$

When any of the structures are repaired, a splint should be applied that provides stabilization in the appropriate position. We recommend hospitalization when there is a need for close follow-up in terms of hematoma and infection and occasionally when there is reason to suspect possible discontinuation of antibiotic therapy at home. Another important issue to be considered is the tetanus prophylaxis, which has been shown to be overlooked in a significant number of cases. In one study, of the 377 patients who initially asserted having had a tetanus vaccine in the last five years, $98(26.0 \%)$ were confirmed to not have received a tetanus vaccine. ${ }^{[17]}$ Similar to a group of cases demonstrated in the study of Tuncer et al., ${ }^{[9]}$ seven of our 23 elective patients had ignored being examined for their wounds at the time of injury, and thus had not received the appropriate prophylaxis although it was needed. This analysis set forth the importance of the booster dose of tetanus toxoid-containing vaccine every 10 years.

Some comorbidities may have an impact on accident development or sometimes constitute the main etiologic basis for the event causing the injury. Thus, investigating additional medical problems should not be overlooked, as $18.6 \%$ of our patients had comorbidities including psychiatric disorders at the time of the injury.

In conclusion, despite the commonness of the subject, some aspects may remain overlooked. Compared to the FB penetrations of the skin or soft tissues of the other body sites, modalities slightly differ when the injured site is the hand or wrist, where there is a higher probability of neurovascular, tendinous, capsular, ligamentous, and bony injury. Overlooked partial injuries of these structures may result in sequelae. All penetrant FBs do not require removal; however, exploration of the wound and removal of FBs in the hand and wrist can be regarded as more important because the detection and repair of underlying structural damage is necessary. Emergency physicians, trauma surgeons and hand surgeons should be watchful about the limitations of direct films for imaging wooden FBs, additional health problems of the injured patients, and probable forensic aspects of the events causing this type of injury. Malpractice lawsuits against physicians, concerning retained FBs, represent another considerable issue. A significant number of people fail to present to a healthcare unit after this kind of injury. It is thus important to check the continuity of routine tetanus boosters for people less than 44 years of age, especially industrial workers and those with hobbies that predispose to this kind of injury. Irrigation of the penetrated tissues with diluted povidone iodine solutions is still a preferred procedure. The retrospective nature of this study limits the power of these conclusions. Prospective, controlled, blinded studies will certainly improve our opinions.

Conflict-of-interest issues regarding the authorship or article: None declared.

\section{REFERENCES}

1. Han KJ, Lee YS, Kim JH. Progressive median neuropathy caused by the proximal migration of a retained foreign body (a glass splinter). J Hand Surg Eur Vol 2011;36:608-9.

2. Talan DA, Abrahamian FM, Moran GJ, Mower WR, Alagappan K, Tiffany BR, et al. Tetanus immunity and physician compliance with tetanus prophylaxis practices among emergency department patients presenting with wounds. Ann Emerg Med 2004;43:305-14.

3. Banwell $\mathrm{H}$. What is the evidence for tissue regeneration impairment when using a formulation of PVP-I antiseptic on open wounds? Dermatology 2006;212:66-76.

4. Vukmir RB. Medical malpractice: managing the risk. Med Law 2004;23:495-513.

5. Kaiser CW, Slowick T, Spurling KP, Friedman S. Retained foreign bodies. J Trauma 1997;43:107-11.

6. Centers for Disease Control. Diphtheria, tetanus, and pertussis: recommendations for vaccine use and other preventive measures. Recommendations of the Immunization Practices Advisory committee (ACIP). MMWR Recomm Rep 1991;40;1-28.

7. Kretsinger K, Broder KR, Cortese MM, Joyce MP, OrtegaSanchez I, Lee GM, et al. Preventing tetanus, diphtheria, and pertussis among adults: use of tetanus toxoid, reduced diphtheria toxoid and acellular pertussis vaccine recommendations of the Advisory Committee on Immunization Practices (ACIP) and recommendation of ACIP, supported by the Healthcare Infection Control Practices Advisory Committee (HICPAC), for use of Tdap among health-care personnel. MMWR Recomm Rep 2006;55:1-37.

8. Ozsarac M, Demircan A, Sener S. Glass foreign body in soft tissue: possibility of high morbidity due to delayed migration. J Emerg Med 2011;41:e125-8.

9. Tuncer S, Ozcelik IB, Mersa B, Kabakas F, Ozkan T. Evaluation of patients undergoing removal of glass fragments from injured hands: a retrospective study. Ann Plast Surg 2011;67:114-8.

10. Steele MT, Tran LV, Watson WA, Muelleman RL. Retained glass foreign bodies in wounds: predictive value of wound characteristics, patient perception, and wound exploration. Am J Emerg Med 1998;16:627-30.

11. Levine MR, Gorman SM, Young CF, Courtney DM. Clinical characteristics and management of wound foreign bodies in the ED. Am J Emerg Med 2008;26:918-22.

12. Hamnett NT, Tehrani H, McArthur P. Perch fin foreign body in a paediatric hand. J Plast Reconstr Aesthet Surg 
2010;63:2198-9.

13. Halaas GW. Management of foreign bodies in the skin. Am Fam Physician 2007;76:683-8.

14. Hollander JE, Singer AJ. Laceration management. Ann Emerg Med 1999;34:356-67.

15. Valente JH, Forti RJ, Freundlich LF, Zandieh SO, Crain EF. Wound irrigation in children: saline solution or tap water?
Ann Emerg Med 2003;41:609-16.

16. American College of Emergency Physicians: Clinical policy for the initial approach to patients presenting with penetrating extremity trauma. Ann Emerg Med 1999;33:612-36.

17. Gindi M, Oravitz P, Sexton R, Shpak M, Eisenhart A. Unreliability of reported tetanus vaccination histories. Am J Emerg Med 2005;23:120-2. 